\title{
Lumen
}

Selected Proceedings from the Canadian Society for Eighteenth-Century Studies

Travaux choisis de la Société canadienne d'étude du dix-huitième siècle

\section{Identifying the Insane: Madness and Marginality in the Eighteenth Century}

\section{Allan Ingram}

Volume 21, 2002

URI : https://id.erudit.org/iderudit/1012272ar

DOI : https://doi.org/10.7202/1012272ar

Aller au sommaire du numéro

Éditeur(s)

Canadian Society for Eighteenth-Century Studies / Société canadienne d'étude du dix-huitième siècle

ISSN

1209-3696 (imprimé)

1927-8284 (numérique)

Découvrir la revue

Citer cet article

Ingram, A. (2002). Identifying the Insane: Madness and Marginality in the Eighteenth Century. Lumen, 21, 143-157. https://doi.org/10.7202/1012272ar

Copyright (c) Canadian Society for Eighteenth-Century Studies / Sociéte canadienne d'étude du dix-huitième siècle, 2002
Ce document est protégé par la loi sur le droit d'auteur. L'utilisation des services d'Érudit (y compris la reproduction) est assujettie à sa politique d'utilisation que vous pouvez consulter en ligne.

https://apropos.erudit.org/fr/usagers/politique-dutilisation/ 


\section{Identifying the Insane: Madness and Marginality in the Eighteenth Century}

The borderline is never a secure place, it never forms an indivisible line, and it is always on the border that the most disconcerting problems of topology get posed. Where, in fact, would a problem of topology get posed if not on the border? Would one ever have to worry about the border if it formed an indivisible line? (Derrida 1991, published 1994, 233)

Derrida, as is well known, disputed Foucault's claim to have written, in Madness and Civilization, 'a history of madness itself, in its most vibrant state, before being captured by knowledge' (Derrida 1978, 34), on the quite straightforward grounds that a history of 'madness itself' cannot be written from within the discourse of reason. Foucault's insistence, therefore, that 'Language is the first and last structure of madness, its constituent form: on language are based all the cycles in which madness articulates its nature' (Foucault 1967, 100), would represent a logical impossibility: there is no such thing as mad language, for as soon as madness attempts to articulate its nature it ceases to be madness. Madness, to adopt another Foucauldian phrase, is always in a perpetual elsewhere, beyond articulation through a language that would draw it back to reason and structure. By 1991, speaking on Foucault's influential text, Derrida had not changed his position, but chose instead to stress the significance of borderlines and those 'most disconcerting problems of topology' that trouble not mad discourse but discourses about madness.

I have written elsewhere about the possibility of 'writing and reading madness,' and about the particular problems of sane writing on madness, be it as a novelist, a dramatist, a psychiatrist, or a private individual, in eighteenth-century England. ${ }^{1}$ One particularly problematic border,

1 See Allan Ingram, The Madhouse of Language: Writing and Reading Madness in the Eighteenth Century (London: Routledge, 1991). 
however, is not the line between sanity and madness, but between sanity and imputed madness. For the individual who has been defined as mad, albeit protestingly, and especially for the individual who has been confined as mad, unique stresses exist when trying to secure redefinition in terms of the sane world. The imputedly mad individual seeking re-entry into language and society comes from a margin that is both real and internalised - real because society has physically confined him or her, physically located a real body in a chains and strait-waistcoat madhouse; and internalised because of the known distance between normal social existence and the stigmatic significance of madness in eighteenth-century society. The language of the allegedly mad, therefore, is potentially both sane and not sane, anxiously, or aggressively, adopting the discourse of reason, as if never removed from it, yet speaking too in the knowledge of that elsewhere to which return would confirm the unspeakable. In the discourses of madness, the discourse of imputed madness 'itself' occupies a curious borderland, neither wholly sane nor wholly outlawed, but waiting at the fringes of what is hearable, recollecting what it was like to be sane, or to be thought sane.

By 1754, when he published his Adventures of Alexander the Corrector, Alexander Cruden had spent a large part of his life inhabiting the margins of sanity and society. The pamphlet itself relates and protests at his third known confinement for imputed insanity. The first such occasion was in the early years of the century, when Cruden as a young man was held as deranged for a short while in the tolbooth of his native Aberdeen at his parents' request. Born on 31 May 1701 and brought up as a strict Presbyterian, he had become involved in a romantic engagement of which William and Isabel Cruden strongly disapproved. He was, as a consequence, sent, in his early twenties, to live in England, where he first found an appointment as reader in French to the Duke of Sussex - short-lived when the Duke realised that Cruden had no knowledge of French pronunciation - and then as a corrector of the press in London. He subsequently also opened a small bookshop near the Royal Exchange, from where he published in 1737 his outstanding Complete Concordance to the Bible, for which he is now mainly remembered. In March of 1738 , however, he was taken into confinement for a second time, to Wright's private madhouse at Bethnal Green, at the instigation of a fellow Scot, Robert Wightman, and again as the result of romantic intentions, his courting of the recently widowed Mrs Payne. Two pamphlets of protest followed Cruden's nine weeks of confinement, The London Citizen Exceedingly Injured, published in 1739, and Mr. Cruden Greatly Injured, published 
in 1740. At the same time he pursued a legal action for damages against Wightman, and lost. ${ }^{2}$

By the time of his third confinement in 1753, Cruden's position as a strict Presbyterian, perceiving all around him the profanity and immorality of London, had apparently obliged him to adopt a more aggressive social role as corrective to his society's neglect of religious obligations. He had therefore extended his professional function as a corrector of the press to a self-appointed position as 'Alexander the Corrector' of the nation's morals, with particular vigilance over swearing and sabbathbreaking. It was during the execution of these duties on Monday 10 September that he became involved with 'several persons' in 'some skirmishing or fighting' in Southampton Buildings. One young man, says Cruden, 'appeared in time of battle with a shovel or spade in his hand, and was guilty of swearing in the presence of Alexander, which so greatly offended him that, contrary to his usual custom, he took his shovel and corrected him with some severity' (Cruden 1754, 5-6). The following day Cruden found himself taken and transported to Inskip's private madhouse in Chelsea, at the instigation of his sister, Mrs Isabella Wild. He was held for seventeen days. On his release he took the same legal action against Isabella as he had against Wightman, and lost, and again published a work of protest, The Adventures of Alexander the Corrector.

Cruden's apparently instinctive turning to print in order to correct what he regarded as an outrageous invasion of his rights is indicative of the position of the madman, and especially of imputed madness, within eighteenth-century English society. The actual scale of confinement of the insane, in Bethlem or St Luke's, the capital's large public asylums, or in one of many small private madhouses across the country, is capable of over-statement, and, as is well known, Foucault's'age of confinement' has been modified and refocused over the last two decades of scholarship. Confinement, however, had other, more insidious consequences than straightforward deprivation of liberty, not least the narrowing psychological impact of being defined as insane, and the implications of that narrowing for the individual's possession of and participation in linguistic expression. The long declaration on the title page of Cruden's

2 For details of Cruden's life, see Edith Olivier, The Eccentric Life of Alexander Cruden (London: Faber, 1934); Roy Porter, A Social History of Madness: Stories of the Insane (London: Weidenfeld and Nicolson, 1987); and Voices of Madness: Four Pamphlets, 1683-1796, ed. Allan Ingram (Stroud: Sutton Publishing, 1997), which includes the text of The London Citizen Greatly Injured. 
first protest pamphlet of 1739 shows how he, at least, felt the need to break out of an assigned role as released lunatic and assert his right to linguistic outrage:

The London-Citizen Exceedingly Injured: Or A British Inquisition Display'd, In an Account of the Unparallel'd Case of a Citizen of London, Bookseller to the Late Queen, who was in a most unjust and arbitrary Manner sent on the 23d of March last, 1738, by one Robert Wightman, a mere Stranger, to a Private Madhouse. (Cruden 1739, 23)

The insistence on titles (Cruden, after repeated applications, had been appointed to the vacant post of Bookseller to Queen Caroline in 1735), the claim to representative status, the citing of names and dates, and the emphasis on manner and interpretation all bespeak an individual anxious to be recognised as once more within the fold of common sanity and common language. In this respect, he joins with those other protesters of his period, James Carkesse, Samuel Bruckshaw, William Belcher, and even Christopher Smart, who assert a central and consistent identity as they take charge in language of rights denied them in practice. ${ }^{3}$ When one's sanity has been nullified, then language is the first recourse in order to reclaim it. Conversely, when John Haslam, apothecary to Bethlem Hospital, wanted to prove that his patient, James Tilly Matthews, should remain confined in 1810, he simply published samples of Matthews' language: 'James, Absolute, Sole, \& Supreme Sacred Omni Imperious Arch Grand Arch Sovereign Omni Imperious Arch Grand Arch Proprietor Omni Imperious Arch-Grand-Arch-Emperor-Supreme etc.' (Haslam 1810, lvii) Matthews' application for release was rejected.

Again, while confinements might not have been so very numerous, the image of the madhouse loomed large in the eighteenth-century public imagination, and afforded only very restricted models for the imputed lunatic. Caius Gabriel Cibber's giant stone statues, 'Melancholy Madness' and 'Raving Madness,' that guarded the gates of Bethlem, marked dreadful boundaries. Beyond these forms, language and sanity

3 For James Carkesse, see Lucida Intervalla: Containing Divers Miscellaneous Poems (1679), ed. Michael V. DePorte (Los Angeles: University of California Press, 1979); for Samuel Bruckshaw's One More Proof of the Iniquitous Abuse of Private Madhouses (1774) and William Belcher's Address to Humanity (1796), see Voices of Madness: Four Pamphlets, 1683-1796, ed. Allan Ingram (Stroud: Sutton Publishing, 1997); and for Christopher Smart, see particularly Jubilate Agno, in The Poetical Works of Christopher Smart, ed. Karina Williamson (Oxford: Oxford University Press, 1980). 
had no meaning: these were the edges of social tolerance and understanding. Science, reason, morality, religion were all rebuffed by their grim exteriors. Cibber, like Pope and Hogarth in their respective fields, set madness as a mark beyond which imagination was not invited. Lunacy in representation was an end, a point where common humanity stopped and emblematic significance began. It is a significance that sustains Pope's lines at the opening of the 1743 Dunciad, with Pope also playing on the fact that Cibber's son was by then poet laureate:

Close to those walls where Folly holds her throne, And laughs to think Monroe would take her down, Where o'er the gates, by his fam'd father's hand Great Cibber's brazen, brainless brothers stand ...

(Pope 1743, 1: 29-34)

The mad individual was reduced to spectacle - the spectacle of representing moral meaning, where humanity had dissolved into the animalistic, the morally chaotic, and the spectacle that was public entertainment. Pope's and Hogarth's lunatics, and their asylum scenes, were the polite, literate versions of actual visits to Bethlem, where extra attendants had to be hired on public holidays in order to restrain those inmates taunted by numbers of visitors to excesses of violence or mischief. ${ }^{4}$ (St Luke's, on the other hand, founded in 1750 by the progressive William Battie, rejected on principle the admission of spectators.)

Between melancholy and raving madness, between moral warning and public sport, the imputed lunatic was marginalised to a very special and very remote spot, and one from which return was discouraged. Cruden, escaping under cover of darkness from Wright's private madhouse on 31 May 1738 (his birthday), and hurting his foot in the process, took a most circuitous walk back from Bethnal Green to the City, apparently avoiding at all costs the direct route that would have taken him past Bethlem Hospital. Indeed, even while suffering from beatings, chaining by the foot, handcuffing and the strait-waistcoat at a private madhouse, where he had been admitted on the authority of a virtual stranger, Cruden's greatest terror was that his persecutors would contrive to have him sent to Bethlem, clearly a point of no return even for the confined mind. Equally, in 1753, held within Inskip's, his dread was

4 See, for example, Bethlem Hospital Committee Books. 1764-79, in Three Hundred Years of Psychiatry: 1535-1860, ed. Richard Hunter and Ida Macalpine (Oxford: Oxford University Press, 1963) 427-9. 
that he would be sent to St Luke's, even though there was almost no control over or inspection of privately run establishments until at least 1774 when legislation established a minimum of safeguards. Medically, too, the mad patient was in practice marginalised. While held at Wright's, Cruden's treatment, prescribed by Dr James Monro, at that time physician to Bethlem and himself owner of a private madhouse, amounted to vomits and bleedings, the traditional purgative and depletive therapies that continued to be used throughout the century. Medical science, for most of this period, had made little progress in, and in fact had no real interest in, easing the return of the insane. This was in spite of the dramatic professionalisation of psychiatry as the century passed and a wealth of specialised psychiatric publication, especially on more fashionable aspects of mental disturbance such as vapours, spleen and hypochondria, and on idiosyncratically espoused favourite treatments, such as shock therapies, opium, camphor, steel, or various privately concocted curatives.

Cruden, in 1753 and 1754, as in 1738 and 1739, showed every determination to return, and his response to the social and medical marginalisation of confinement in a madhouse was robust and self-assured, of a piece with his conduct throughout his life. The Adventures of Alexander the Corrector asserts not only Cruden's sanity but reaffirms the standards of behaviour and belief that brought him to the madhouse at all. Again, the title page sets out the complete agenda. The pamphlet is 'An Account of the Chelsea-Academies, or the Private Places for the Confinement of such as are imputed to be deprived of the Exercise of their Reason.' It is also, with respect to Cruden's own role, 'An Account of the Prophecies of some pious Ministers of the Gospel, foretelling that ALEXANDER's Afflictions are designed by Divine Providence to be an Introduction and Preparation to his being a JOSEPH and a prosperous Man.' The whole, finally, is offered 'With Observations on the Necessity of a Reformation by executing the Laws against Swearers, Sabbath-breakers, and other Offenders' (Cruden 1754, 1). Moreover, the work is unashamedly dedicated 'To His Royal Highness William Duke of Cumberland, CaptainGeneral and Commander in Chief of his Majesty's Forces' (Cruden 1754, 2), a man whose name was by 1754 , with Culloden only eight years past, for many Scots synonymous with butchery. Cruden, however, buckles Cumberland's reputation firmly to his own agenda, both in terms of religion and of destiny:

I was induced to make this Address to your Royal Highness by the great Affection I have for the KING and every Branch of the Royal Family, particularly for your Royal Highness, whom the great Governor of the World hath in a signal manner honored to be the Deliverer of all his MAJESTY's Subjects from Popery 
and Slavery, by the complete Victory you obtained over the Rebels at Culloden, for which your Name will be greatly celebrated by Generations yet unborn.

THE Death-stroke which your Royal Highness hath given to the Cause of Jacobitism, lays a lasting Obligation on all true Protestants to offer up ardent Prayers for your attaining to Happiness here by seeking and serving GOD through JESUS CHRIST, and for your being made Partaker of eternal Blessedness and Glory hereafter. (Cruden 1754, 3-4)

Cumberland's centrality to God's design, against popery as against Jacobitism, makes him as appropriate a model for Alexander the Corrector, enforcing the Lord's ordinances on earth, as he is for a marginalised Scottish Presbyterian in London trying to reposition himself after a spell in a madhouse.

Crucial to Cruden's self-presentation in this pamphlet is his assumption of what he regards as a sane identity, or rather two identities, one of them based in a present, or at least in a past as recent as his own behaviour prior to confinement, and the other in a past historically remote, but brought into the present by an accident of names. As Alexander the Corrector he is able to combine both his everyday professional activity and his destined providential function and to overlay them with the martial glory and heroic stature of Alexander the Great. In martial terms, the battle analogy runs from the title page and his Chelsea-Campaign' (Cruden 1754, 1), through reference back to 1738 and 'his campaign at Bethnal-Green' (Cruden 1754, 14) and through constant allusion, too, to the recent 'battle of Southampton' (Cruden 1754, 18), binding Cruden, Cumberland and Alexander in a formidable trinity of generalship. But Alexander offers more than a military presence for Cruden. All those qualities that are most remote from insanity - judgment, justice, reasonableness, patience, resolution and justifiable severity - are consummated in his celebrated role model: he is, says Cruden, 'like Alexander the great who used to set up a piece of candle before a town, and if they submitted before it went out, then they had safety and protection; if not, they were put to the sword' (Cruden 1754, 33). Indeed, as Alexander the Corrector, Cruden combines both distance from, and proximity to, the context of his being defined as a madman - a position uniquely suited to those 'disconcerting problems of topology' that he intends to pose. As Alexander the Great, he is himself heroic, strong, a relentless judge and agent of retribution, above and removed from the pettinesses of everyday humanity, of eighteenth-century London, of the conspiracies among family and acquaintances, the 'tutors' at the Chelsea 'Academies.' As 'Corrector,' on the other hand, he has a predestined duty to probe into the moral and religious shortcomings of human conduct, and especially of those who would define him as mad. 
So, Cruden's pamphlet, while framed in the heroic mould, is also filled with 'correcting.' This commences, most dramatically, with the 'shovel' incident, but extends to private comment and public reproaches throughout the narration. 'Mr. Duffield,' for example, uncle to Inskip and himself a madhouse keeper, is censured for 'coming from Glocester-Street to Little-Chelsea every sabbath, and giving his patients a bad example by not attending public worship, but passing his time in an idle manner among them,' and for allowing his tailor to bring down clothes and patterns, 'which was far from keeping the sabbath' (Cruden 1754, 10). On the journey to Chelsea, Cruden and his coachman witness a man in the street, encouraged by a crowd of onlookers, 'severely beating a wicked lewd woman' who is suspected of having stolen his guineas. 'On this occasion,' says Cruden, the 'Corrector lamented the wickedness of this great city. May God in his providence raise up instruments to reform us before we be utterly destroyed!' (Cruden 1754, 9) 'Acott,' a tailor, is 'corrected' for the turbulence of his marriage:

In some parts of this Island persons of good character will hardly speak to husband and wife that quarrel with one another, or give one another blows, or threaten to do it. Some think that such criminal persons deserve transportation, at least the most guilty person, to prevent the contagion of a bad example; for the violation of the laws of marriage, by living in quarrelling and strife, is perjury. (Cruden 1754, 13)

And Inskip himself, the representative of sane society's preference to be protected from the insane, is found severely wanting in virtually every respect, not least in his ability to distinguish between madness and sanity:

This man has so little judgment or discerning, that the Corrector thinks, if the college of physicians, to make trial of his skill, should send one of the most solid and most judicious of their fellows to be under Inskip's care, he would from ignorance, stupidity and cowardice, treat him like a Tom of Bedlam, by tormenting him with the Strait-Wastecoat and other severe usage. (Cruden 1754, 10)

Towards the end of his piece, Cruden observes that 'Alexander instead of being a Corrector of the Press, is now become a Corrector of the People' (Cruden 1754, 36), and it is with regard to Inskip that the specific connection between behaviour and printing is made, a connection that underlies Cruden's whole occupational outlook:

The Corrector told this wrong-headed man again and again, that he was like a certain Master-Printer's pressman, of whom their master said, That if there were 
ninety nine ways of doing a thing right, and one wrong way, they would take the wrong way. (Cruden 1754, 10)

Alexander the Corrector of the Press inspects printed matter, correcting wrong letters, spaces, fonts, paragraphing and margins. Peripheral to the printing process, neither preparing copy nor setting up type, he is nevertheless critical in the final presentation of the text. His detached judgment is central to the rectitude of the published page. Alexander the Corrector of People has the responsibility to examine minutely into contemporary conduct, scrutinising his fellow mortals through the omissions and inclusions of their moral rectitude, exploring the very type of human fallibility. Peripheral to the content of their lives, their private personalities and experiences, his business is with those principles of right and wrong that pertain irrespective of personality or experience. As such, his judgment is central to a final assessment of his society's spiritual welfare. Detachment from and involvement with find their ultimate expression in the voice of Alexander the Corrector, albeit a voice that comes by way of the madhouse.

The individual most in need of exemplary correction, for Cruden, is quite close to home. His sister, Isabella Wild, who is responsible for his confinement, represents therefore the last extreme of wrong judgment and ill-assumed authority. She has attempted to consign to the margins of a madhouse a man who actually stands for right thinking and rightful acting. In fact, it had been only 27 August 1753 when Cruden had been at Isabella's marriage to Wild, 'when he acted at Langley-Church as father to give her away' (Cruden 1754, 7). It also emerges later that Cruden is one of Isabella's guardians (Cruden 1754, 31) - a curious circularity in which Cruden, having once been confined as mad by his actual father, has now also been confined as mad by the relation to whom he in effect stands as father. Isabella is guilty of having acted hastily, of having 'adopted with all readiness the false and silly notions' of 'three wrongheads' with regard to the Corrector's behaviour at Southampton Buildings, in which, says Cruden, she is following the example of their 'excellent mother' who was 'apt to act in the same manner' during their father's magistracy (Cruden 1754,7). Isabella's correction is to be speedy and dramatic, as Cruden reasserts his authority as father and corrector:

Madam, You deserve to be sent to Newgate, and if you was worth ten thousand pound, you deserve to be fleeced of one thousand. From Isabella's being so audacious, a judgment may be formed of her former conduct to the Corrector, and that she deserves to be corrected lest she should be again guilty of the same crime. (Cruden 1754, 26) 
His formal proposal is 'that she voluntarily submit to go to prison in Newgate for the space of forty eight hours' which may be 'lessened a few hours' upon her 'intercession.' While confined, 'she shall in every respect be well used' and is to 'be attended by Mrs. Betty Leslie, Mrs. Wither's chamber-maid' (Cruden 1754, 27). Moreover, 'together with this confinement Isabella is to pay directly to Alexander the sum of ten pounds at her going to prison, or to give security for it before she is set at liberty' (Cruden 1754, 29). Her confinement, says Cruden,

will give her time for a little speculation and meditation, and may convince her that she is fallible, and ought not to be determined by the blind world, especially in affairs of importance, but to look up by prayer to God for counsel and advice.

Cruden will be praying that the experience 'may be a mean of grace being brightned in her soul.' Moreover, he adds, a little less selflessly, 'it will be some acknowledgement of her using the Corrector without due consideration, and tend to vindicate his character, and be to his advantage in several respects' (Cruden 1754, 27-28).

The proposed trade-off did not take place, in spite of Cruden's persistence, his attempt to engage the help of several intermediaries, and his readiness to change the place of confinement when reminded of the health hazards of Newgate:

Friday, October 26, the Corrector being informed that all the rooms in Newgate were liable to communicate the gaol distemper, he writ a letter directly to Mrs. Rayner at Colnbrook Mr.Wild's sister, signifying that he dropt Newgate and would desire an imprisonment for twice forty-eight hours in the Tower, and the sum of fifteen pound. (Cruden 1754, 32)

One intermediary, much against Newgate on the grounds 'that no occasion might be given to the opprobrious name of a Newgate-bird,' neverthless thought 'he could get her sent to Reading-Gaol. Ailsbury-Gaol and the prison in Windsor-Castle were also mentioned' (Cruden 1754,31). In the event, Isabella and her husband, understandably, refused to co-operate, and the pamphlet ends not with a public demonstration of her error but with Cruden's falling back on linguistic self-assertion and on written testimonials reprinted from The London-Citizen of 1739 as evidence of his sanity.

What the attempted exchange demonstrates, however, with Cruden's assumption of proprietorial rights over Newgate, the Tower of London, and, by implication, the English legal and penal systems, is how far a return from the margins of sanity must involve not just a reassertion of family authority but a retaking of the heights of major social institutions. 
Cruden would have himself virtually stand for the principles of justice, as he did in the title of The London-Citizen Exceedingly Injured. In fact, in putting himself forward as corrector, he is at the same time implicitly, and occasionally explicitly, staking a claim to exemplify those standards which he finds so problematic in other models, thereby effectively inserting himself into the most serious and significant roles of his society, of law, church, state, medicine and culture. Imputed madness strikes back, bidding for the very core of the social fabric.

It is in religious matters, most obviously, that Cruden finds the established incumbents questionable in terms of reforming the very 'visible' state of 'degeneracy and corruption of this nation' and himself so curiously fitted for the task:

It may seem surprising that the Corrector, a person of a retired situation in life, should be so zealous in this grand affair, when persons in the highest stations in Church and State seem to be too silent, and not to exert themselves with a steady resolution and zealous vigour to reform the nation. But if the work be done, the instruments are to be less minded, because the great God often brings about the greatest matters by mean instruments. (Cruden 1754, 43)

But he does not shrink, either, from asserting the standards to be expected from a range of public functionaries, officers and institutions. Magistrates 'are to be exemplary, and not be guilty of swearing and sabbath-breaking as is sometimes the lamentable case' (Cruden 1754,44). British cultural life participates in the degeneracy of the nation, with the stage a prime influence and 'men and women of the stage' being castigated as 'the corrupters of the minds of the people' who 'deserve to be treated as persons that are hurtful to society and pollute the minds of his Majesty's subjects' (Cruden 1754, 41). Physicians, specifically John Monro, son of the Monro who prescribed at Wright's madhouse in 1738, have an obligation to hold to correct political and moral principles, and Cruden, who at one stage 'began to think of a Recipe for the Doctor ... to effect a change in his behaviour and conduct in life' (Cruden 1754, 18), actually warms to Monro 'because he heard that he was not a jacobite nor an adulterer, as was reported of a certain maddoctor' (Cruden 1754, 23). (The allusion is in fact to Monro's father.) Even the Royal family is subject to assessment alongside Cruden's own standards, and happily found to be admirable for their 'legal and mild administration,' especially in comparison to the Stuarts, who 'had been but indifferent rulers' and of whom Cruden 'was apt to think that divine Providence had decreed that they should never reign in this island' (Cruden 1754, 33).

Inevitably, Cruden does not stand alone in representing standards of judgment and behaviour to his people. Rather, he is supported through- 
out by Providence, 'which always appeared for the Corrector' (Cruden 1754, 35). 'God,' he declares,

doth great and mighty wonders in his Providence, which is always righteous yet often mysterious, and he by his secret power and wisdom can bring about great and valuable purposes by seeming contrary means, for he hath all things in his hand and under his control, and is the God of the whole earth. (Cruden 1754, 39)

Moreover, the interest of divine Providence also gives sustenance to Cruden's other major, milder role model for this and indeed for his previous pamphlets, that of the biblical Joseph whose significance is attested to on the title page. It is Joseph who makes sense, for Cruden, of his hardships and suffering in a way that Alexander the Great could not, and Joseph, too, who allows the entry of the Christian God into the chronicle of a pre-Christian conqueror.

And who knows but it may appear in due time that God designs that Alexander shall be a Joseph and after his humiliation a prosperous man; for it is often the method of divine Providence to make a state of humiliation a preparative for that of exaltation; and Solomon says again and again, Before honour is humility. (Cruden 1754, 28)

If Alexander secures for Cruden the power he now exercises as corrector and questioner, it is Joseph who brings into focus the Lord's intentions in allowing suffering, in exacting meekness under humiliation, as a preparation for greatness within the society that has banished him, for a time, to so uncomfortable a periphery.

Cruden, then, makes in The Adventures of Alexander the Corrector a serious and sustained assault on the most significant features of his society, both its manners and morality and its institutions and functionaries. At the same time - and this, too, is a feature of the 'disconcerting' nature of his literary personality - what no reader can miss in his writing is an exuberance and an infectious energy which give, paradoxically, a strong tone of playfulness to his experiences and attitudes. Often, he seems even to stand bemused and captivated at the edges of his own experience - an impression strengthened by his insistence on referring to himself in the third person - ready to laugh at the oddness of it all. This is particularly so as he settles into Inskip's madhouse. While being transported there, he is struck that the chairmen who tied and guarded him 'went by the names of Michael and Matthew' (Cruden 1754, 8). Once installed, he meets some of the other inmates: 'In the evening the Corrector was favoured with the company of George King, a patient that had been in Inskip's house about ten days, and was sometimes called King 
George, his name giving occasion to that appellation' (Cruden 1754, 12). Indeed, Cruden indulges in some playful naming of his own, deciding to give one of the 'conspirators' against himself 'the emblematical name of Moonland' (Cruden 1754, 12). There is even a humourous keeper, John Thompson, who claims to have been lord mayor of York, but 'with no other foundation than that there was an alderman at York of the name of Thompson who had been once and again mayor of that city' (Cruden 1754, 11). Cruden 'asked John Thompson, how many madhouses there were in Chelsea? he answered, none; for, said he, Nothing ails the houses' (Cruden 1754, 11).

Cruden's experiences at Inskip's certainly include deprivation and abuse, but the whole establishment, and Cruden with it, takes on at times a tone as enigmatic as a Shakespearean gravedigger's. Cruden participates during a conversation with Inskip's wife:

She seeming satisfied that the Corrector was no madman, put to him an uncommon question, Whether he was ever mad? He answered, That he was as mad now as he was formerly, and as mad then as he was now: that is to say, not mad at any time. (Cruden 1754, 16)

Most bizarrely, once Cruden has embarked on a hunger strike in order not to have the ostler, Hare, attend on him, there is a jocular scene of forced feeding, with 'Inskip's wife, who wanted to force down milk-porridge in the former way; but she did it very gently, Jones holding the instrument in the Corrector's mouth; all three were much diverted, and laughed at this scene' (Cruden 1754, 19). It is as if nothing can be taken wholly seriously, and nothing, apparently, quite at face value:

He asked John Thompson what the white tossel of the bed was an emblem of? John answered, Of innocence. What was the curtain an emblem of? The House of Orange; they were of an Orange colour. What the coverlid typified? He answered, that it represented the Flower-de-luce and old Shackleton: it is supposed he meant old Lewis XIV. that put the protestants in chains and shackles. (Cruden 1754, 11)

Alexander's adventures, similarly, proceed through a mock landscape, involving emblematical battles, albeit with a real shovel, campaigns and decampments (Cruden 1754, 24), encounters with 'tutors' and'Myrmidons' at the Chelsea 'academy' (Cruden 1754, 8), and a 'whimsical and extraordinary' (Cruden 1754, 29) peace proposal for his sanctimonious sister.

At one level, Cruden takes seriously his confinement, his treatment, his rejection by society, and uses them to pose 'disconcerting' questions about society's values and practices, about its definitions of madness. He 
demands recompense and recognition. Yet at another level his experience is 'emblematical': it does not mean what it seems to mean. God, certainly, is attaching Providential intentions to the 'adventures,' and that is not to be taken lightly. But the tone of so much of the presentation is itself light, even dismissive of the encounters with individuals and institutions, that everything seems to be put there to be made fun of and laughed at. John Thompson 'seemed to exert himself to divert the Corrector' (Cruden 1754,11). Cruden is very ready to be diverted by much of what he meets while out adventuring, and in his turn is quite prepared to play his part in mimicking, deflating and subverting conventional authority from his position on the borderline. If the doctor is to write the madman 'a Recipe,' then the madman must write one for the doctor. Cruden as imputed lunatic, confined, medicated, strait-waiscoated, rather enjoys the freedom to act the jester and madman that such extreme marginalisation gives him.

Cruden's life after The Adventures itself represents a continuation of the mock serious attitudes played out in the pamphlet. In the same year as its publication, he stood for election to the House of Commons as candidate for the City of Westminster where Sir John Barnard, sitting member since 1722 and a former lord mayor, was seeking re-election. (It was Sir John, ironically, who had officially released Cruden from his earlier confinement in 1738.) Cruden, on religious grounds, would consent to serve only if elected unopposed, and consequently withdrew his candidature. However, if the British parliament remained closed to him, Cambridge University proved more amenable and apparently knighted him in a mock ceremony during one of his visits. He also paid long and persistent court, entirely by letter, to Elizabeth Abney, whom he had never met, the daughter of another former lord mayor, again in the declared belief that, like Joseph, he was fulfilling God's intentions in doing so. In this campaign, too, he was unsuccessful. Towards the end of his life he became active in prison welfare, apparently effectively. $\mathrm{He}$ died aged sixty-nine on 1 November 1770, on his knees in prayer at his lodgings in Camden Passage, Islington.

'Language is the first and last structure of madness; on language are based all the cycles in which madness articulates its nature' (Foucault $1967,100)$. We cannot claim the right to decide whether Cruden was ever insane. He did, however, resort to language as the first and last structure of sanity in order to redeem himself from having been defined as mad, a serious attempt to effect a return from the madhouse and to prove that his sanity was in fact central to his society's real concerns, concerns that could only be clearly seen from the insecurity of a borderline. That language, generated from an imputed edge, had, as he saw it, to be loud and distinct. Inskip's was a long way from the centre. But Cruden also 
had God on his side, along with Alexander the Great, Joseph and the Duke of Cumberland, which gave his linguistic resources considerable weight and his self-articulation a remarkable degree of assurance. Swift, a master in posing 'disconcerting problems of topology,' had argued in the 'Digression Concerning the Original, the Use, and Improvement of Madness in a Commonwealth' in A Tale of $a$ Tub, that mad individuals were misplaced in an asylum, that their talents belonged firmly within distinctive social groups to which they should be straight away restored. Cruden, fresh from the madhouse, executed the perfect borderline manœuvre and attempted not to rejoin society but to have society join him.

\section{ALLAN INGRAM}

Northumbria University

\section{Works cited}

Cruden, Alexander. The Adventures of Alexander the Corrector (London: for the author, 1754).

Cruden, Alexander. The London Citizen Exceedingly Injured (1739), in Voices of Madness: Four Pamphlets, 1683-1796, ed. Allan Ingram (Stroud: Sutton Publishing, 1997).

Derrida, Jacques. "'To Do Justice to Freud": The History of Madness in the Age of Psychoanalysis.' Trans. Pascale-Anne Brault and Michael Naas. Critical Inquiry 20 (Winter 1994).

Derrida, Jacques. Writing and Difference. Trans. Alan Bass. Chicago: University of Chicago Press, 1978.

Foucault, Michel. Madness and Civilization. Trans. Richard Howard. London: Tavistock, 1967.

Haslam, John. Illustrations of Madness. 1810. Ed. Roy Porter. London: Routledge, 1988.

Ingram, Allan. The Madhouse of Language: Writing and Reading Madness in the Eighteenth Century. London: Routledge, 1991.

Pope, Alexander. The Dunciad. 1743. Ed. James Sutherland. London: Methuen, 1963.

Swift, Jonathan. A Tale of $a$ Tub. 1704. Eds. A.C. Guthkelch and D. Nichol Smith. Oxford: Oxford University Press, 2nd edn, 1958. 